\begin{tabular}{|c|c|c|}
\hline U N I V & $\begin{array}{l}\text { A N A L E } \\
\text { MARIAE C } \\
\text { BLIN - POI }\end{array}$ & \\
\hline VOL. XXXVIII & SECTIO FF & $1-2020$ \\
\hline
\end{tabular}

ISSN: 0239-426X • e-ISSN: 2449-853X • Licence: CC-BY 4.0 • DOI: 10.17951/ff.2020.38.1.97-111

\title{
Trapped by Femme Fatale in the World without Order: The Simple Art of Hard-Boiled Fiction and Film Noir*
}

\author{
Uwięziony przez femme fatale w świecie bezprawia: \\ prosta sztuka powieści hard-boiled i filmu noir
}

\author{
KRZYSZTOF ANTONIAK \\ John Paul II Catholic University of Lublin, Poland \\ ORCID ID: https://orcid.org/0000-0002-0273-8151 \\ e-mail: krzysztof.antoniak@kul.pl
}

\begin{abstract}
The article presents the beginnings of the hard-boiled novel and film noir, which date back to the 1920s and 1930s. Difficult economic and political conditions of that time gave rise to the new genres in literature and cinematography. The classic novels by Raymond Chandler and Dashiell Hammett present a world, where crime goes unpunished and order can never be restored. An important role in novel narrative, enabling the authors to build such a vision, is played by the city, presented as a labyrinth that lures the main character in. A lonely detective fights against injustice and often falls for a femme fatale, who abuses him for her own purposes. The paper analyses the history, evolution and characteristics of the literary genre in order to showcase the impact of hard-boiled novels on film noir, as well as to outline the principles of "simple" art of hard-boiled novels and film noir.
\end{abstract}

Keywords: Raymond Chandler, Dashiell Hammett, hard-boiled novel, film noir, detective, femme fatale, city, crime

* The volume is funded from the budget of the Institute of Polish Studies of Maria Curie-Skłodowska University, from the funds of the Minister of Science and Higher Education for activities promoting science (contract no. 615/P-DUN/2019) and under the "Support for Academic Journals" programme (contract no. 333/WCN/2019/1 of 28 August 2019). Publisher: Wydawnictwo UMCS.

Contact details of the author: Institute of Literary Studies, John Paul II Catholic University of Lublin, 14 Racławickie Av., 20-950 Lublin, Poland, phone: +48 814453052. 
Abstrakt. W artykule przedstawione zostały początki powieści hard-boiled i filmu noir, które sięgają lat 20. i 30. XX wieku. Trudne warunki ekonomiczne i polityczne tamtych czasów dały początek nowemu gatunkowi literatury i kinematografii. Klasyczne powieści Raymonda Chandlera i Dashiella Hammetta przedstawiają świat, w którym zbrodnia pozostaje bezkarna, a porządku nigdy nie udaje się przywrócić. Ważną rolę w budowaniu takiej wizji odgrywa w narracji powieściowej miasto przedstawione jako labirynt wciągający głównego bohatera. Samotny detektyw walczy z niesprawiedliwością i często zakochuje się w femme fatale, która wykorzystuje go do własnych celów. Artykuł analizuje historię, ewolucję oraz cechy charakterystyczne gatunku literackiego i wskazuje wpływ powieści hard-boiled na filmy noir, przedstawiając zasady „prostej” sztuki powieści hard -boiled i filmu noir.

Słowa kluczowe: Raymond Chandler, Dashiell Hammett, powieść hard-boiled, film noir, detektyw, femme fatale, miasto, zbrodnia

Although the title of the article may suggest that defining hard-boiled fiction and film noir is simple and should not be demanding, especially for an avid reader or a well-educated critic, it is a far cry from the truth. The phrase "the simple art" refers to the famous critical essay The Simple Art of Murder written by one of the forefathers of hard-boiled fiction, Raymond Chandler. Just like Chandler who uses his title provocatively claiming that there is nothing simple in creating a literary masterpiece, this article also attempts to manifest a not-so-simple art of understanding hard-boiled fiction and film noir. The aim of this article is to scrutinize the origins and beginnings of these genres and to provide the reader with concise yet thorough examination of this topic. The analysis excludes the notion of contemporary neo-noir, as the subject opens up a vast array of ideas and concepts, making it difficult to exhaustively and sufficiently investigate both the classic noir and neo-noir in such a short piece of writing. However, extraordinary and marvellous the contemporary neo-noir films are, it is vital to remember that they all refer, in one way or another, to what is known as a classic period; therefore, in order to be able to understand the contemporary neo-noirs, one has to hark back to the past and analyse the classic genre.

\section{FOREFATHERS OF HARD-BOILED FICTION}

The 1920s and 1930s brought an evolution in crime fiction, giving rise to hardboiled literature, which was a lurking and unsettling type of fiction (Horsley, 2005, p. 76). A well-known film critic Gene D. Phillips writes: "Hard-boiled fiction was so named because the tough detective-hero developed a shell like a hard-boiled egg in order to protect his feelings from being bruised by the calloused and cruel criminal types he often encountered" $(2012$, p. 6). The undisputable forefathers of hard-boiled fiction are Raymond Chandler and Dashiell Hammett, who "not only 
helped make detective fiction respectable, but helped raise it to the lofty level of literature" (Phillips, 2012, p. 6). The first hard-boiled stories appeared in the pulp magazine, Black Mask, in 1923 (Philips, 2012, p. 7). Black Mask was founded by George Jean Nathan and Henry Louis Mencken in 1920, yet it was sold in 1922. The new owners decided to turn to adventure, Western and crime stories and focus on realistic action (Horsley, 2005, p. 76). Between 1926 and 1936, Joseph "Captain" Shaw was the editor of Black Mask and this was precisely the period when the pulp magazine flourished. The stories published here leaned more towards the American hard-boiled fiction rather than British detective stories (Phillips, 2012, p. 7). In 1923, the first detective stories written by Dashiell Hammett were published in the magazine and a decade later Raymond Chandler published his hard-boiled stories here (Horsley, 2005, p. 76). After Black Mask became a success, other pulp magazines, such as Detective Fiction Weekly, Dime Detective, or Black Aces followed its steps, however, it was Black Mask that was at the leading edge and was the first to publish the stories about hard-boiled detectives (Horsley, 2005, p. 76).

When asked about Dashiell Hammett's work, Raymond Chandler said: "Hammett gave murder back to the kind of people who commit it for reasons [...]. He put these people down on paper as they are, and he made them talk and think in the language they customarily used for these purposes" (qtd. in Phillips, 2012, p. 4). Born in 1894 in Maryland, Hammett held many different positions. In his early twenties he started working in the Pinkerton Detective Agency, where he gained insight into the profession of a private investigator. His detective career was interrupted by World War I, during which he served in the army. When the war ended, he returned to the agency, only to leave it in 1920 when his illness worsened (Mayer, 2007b, p. 33). At the beginning, he failed to catch the public attention with his fiction, but in 1923, when his stories about the detective, known as Continental Op, were published in Black Mask, he successfully found his own niche (2007b, p. 34). The stories published in the pulp magazine were the basis for Hammett's novels. After publishing The Maltese Falcon (1930), he became a well-recognizable writer even in Hollywood circles. In 1941, the film adaptation of the novel made him even more popular (2007b, p. 34).

The plot in Hammett's novel is built around the corruption of society. Although his detective solves the case, unease remains as a part of the story. The gumshoe is aware of the futility of his struggle to see justice done and realises that a corrupt city environment will eventually foil his attempts to restore the order. Even when the case is closed, the city remains corrupt (Phillips, 2012, p. 5). Describing Hammett's detectives, a British writer Julian Symons claims that "they are three-dimensional characters who bleed, suffer, make mistakes - in fact, human beings" (1985, p. 3). Sam Spade, The Maltese Falcon's detective, is a tough and cynical private eye who maintains a law-abiding individual, even though he has to fight the unlawful 
universe (Philips, 2012, p. 9). Chandler asserted that Hammett's hard-boiled fiction was breaking the British tradition of refined detective fiction (qtd. in Phillips, 2012, p. 4). He openly admitted that it is Hammett, not himself, who is the inventor of hard-boiled detective story: "I did not invent the hard-boiled murder story [...]. I have never made any secret of my opinion that Hammett deserves most or all of the credit" (qtd. in Phillips, 2012, p. 5). Be that as it may, Raymond Chandler is regarded just as significant a writer of hard-boiled fiction as Dashiell Hammett and both writers are considered to be the forefathers of hard-boiled fiction.

Raymond Chandler once said that if an author is not sure where the story should lead, it is always a good idea to have "a man come through a door with a gun in his hand" (qtd. in Phillips, 2012, p. 6). Chandler's protagonists, whether it was Mallory or Marlowe, Dalmas or Carmady, were more traditional than Hammett's characters. In The Simple Art of Murder he writes that a hero should be honourable. He claims that it is vital he be "the best man in his world and a good enough man for any world" (qtd. in Meyer, 2007b, p. 28). Chandler's fiction is also full of melancholia. He expresses contempt for modernity and sadness caused by the feeling of alienation in modern society and mainstream thinking (2007b, p. 28).

Born in 1888 in Chicago, Raymond Chandler had to face harsh reality of life since his childhood. Deserted by his father at the age of seven, he was taken by his mother to London, where he received his education in the classics as well as Latin. In 1904, he graduated from Dulwich Preparatory School only to struggle to establish a career as a writer (Mayer, 2007b, p. 28). Years in service during World War I left their mark on his life and made him develop a penchant for alcohol. In 1924, he married Cecilia Pascal, a woman eighteen years older than him. During the Great Depression, his service at the Dabney Oil Syndicate was terminated due to his drinking problem (2007b, p. 28). This upheaval encouraged him to write and thus he started writing for Black Mask. When Joseph Shaw was no longer the editor of the pulp magazine, Chandler decided to leave the magazine and turned to writing for Dime Detective. Since his salary was not enough to provide an income for him and Cissy, he decided to publish a novel, The Big Sleep. After that, he never wrote anything for any pulp magazine and focused on his career as a novelist (2007b, p. 29).

Chandler's adventure with screenwriting started when he was hired to write a screenplay of Double Indemnity (1944), which appeared to be a great success. Afterwards, he was asked to write a script of The Blue Dahlia (1946), the decision which put the studio in a predicament. Owing to his alcohol addiction, Chandler was unable to finish the script. Moreover, he refused to do so, having been offered a large amount of money to finish the work by the deadline, since he considered it a bribe. Eventually he agreed to write the whole screenplay under certain conditions. 
First, he had to be provided with alcohol, for he was unable to write when sober. Apart from that, he ordered two limousines, so that the pages of the script were transported to the studio, as he refused to do it by himself. In addition to that, he had the script typed for him by three secretaries. Luckily for the studio, he managed to finish the script (Meyer, 2007b, p. 29).

Hammett's and Chandler's detectives speak in urban slang and chase criminals on dark streets of maze-like cities, thus, their stories are "very far removed from the politely cerebral, locked-room mysteries of [Agatha] Christie" (Simpson, 2010, p. 190). Lee Horsley writes that "speech is, then, another quality which distinguishes the hard-boiled form from classic detective fiction, setting the tone of the narrative but also establishing a masculine ethos" (2005, p. 74). The language, wit and a sarcastic smile are the tough detective's armour which provides him with control over chaos, even if his power is just illusory. In The Simple Art of Murder, Chandler states that a hard-boiled detective must be a "common man," in other words, "everyman" (qtd. in Horsley, 2005, p. 72). A private eye uses "verbal combativeness" (2005, p. 72), showing that he is not superhuman but uses a skill that is available to every man so as to "defend himself against a hostile environment" (2005, p. 72).

The hard-boiled protagonists face the world of nightmare, the fallen universe, which shatters their reality. The knight-errant-like characters have to deal with degenerated society and corruption (Simpson, 2010, p. 190). Chandler claims that the aim of the hard-boiled tradition is to portray "the world you live in" (qtd. in Horsley, 2005, p. 68). While the golden age fiction writers create literature that "encodes the socio-political anxieties of their time, hard-boiled writers addressed the problems of their society explicitly" (2005, p. 68). As far as classic detective literature is concerned, Chandler criticized "the socio-political implications of its closed form" (2005, p. 69). The writers of hard-boiled fiction realise that the reality in which the detective is capable of restoring the order is no longer viable, therefore, they structure the narratives in such a way as to avoid the end that would be unrealistically optimistic. In the introduction to Fingerman (1950) Chandler writes that a tough detective:

lived in a world gone wrong, a world in which, long before the atom bomb, civilization had created the machinery for its own destruction and was learning to use it with all the moronic delight of a gangster trying out his first machine-gun. The law was something to be manipulated for profit and power. The streets were dark with something more than night. (Chandler, 1960, p. 5)

In times of Prohibition, proliferation of the mob, the Great Depression and rapid economic and political changes, society needed literature that would present the world as it is, the world in which despair cannot be fought (Horsley, 2005, 
pp. 69-70). Hard-boiled writers brought "a new realism" (2005, p. 70), which represented the "turbulent society" (2005, p. 70$)$, yet this ruthless realism was combined with "the fantastic and the symbolic" (2005, p. 70).

Though writers like Hammett and Chandler established the mood of hardboiled literature, their followers preserved noirish idea, modifying it so that it fits into the 1950s' and 1960s' cultural landscape. The unrest evoked by the Cold War and the Vietnam War transformed hard-boiled fiction, making it even more idiosyncratic and further from mainstream ideas (Simpson, 2010, p. 192). The practitioners of this newly-born type of tough literature approached private eyes reluctantly, choosing instead police detectives as their protagonists. This turn to police procedural was mostly initiated by the trust that "crimes are investigated and sometimes even solved by police departments" (2010, p. 192). The narrative yet still remains focused on the "hazards of a fallen [and] corrupt environment" (2010, p. 192), leaving the law-abiding police detective alone in the pursuit of order.

The novels of writers such as Raymond Chandler and Dashiell Hammett had a great influence on the birth of film noir. Since "their work became known as American noir fiction" (Phillips, 2012, p. 10), the public of the 1930s, which voraciously read the stories of the private eyes, was being prepared for the forthcoming evolution of film noir. The public loved the stories about "bourbon for breakfast, bloody corpses, and shadowy streets lit by garish neon signs" (2012, p. 10).

\section{FILM NOIR AND NEO-NOIRS}

Film noir flourished owing to hard-boiled literature. Crime stories captured public attention, which was caused both by the increase in literacy and the rotary steam press that enabled low-cost production of weekly magazines and newspapers. Raymond Chandler, Dashiell Hammett, Cornell Woolrich and James M. Cain were the authors who influenced noir directors the most. Andrew Spicer claims that almost twenty percent of film noirs produced between 1941 and 1948 were adaptation of American hard-boiled masterpieces (2010, p. xl). Nevertheless, studies have demonstrated that film noir is not a phenomenon which appeared only in America. European, Asian, Australian and Latin American cinemas developed their own versions of the genre which were in many aspects comparable to American films (2010, p. xxxvii). For the purpose of this article, however, it is American film noir that will be the subject of the discussion.

Many critics and commentators cannot reach consensus about what film noir really is. Phillips writes: "once you start looking for noir you see it everywhere. One must be aware that a film must meet certain standards to be considered among the 
classic film noirs. Otherwise one can nominate biker movies and slasher movies as film noirs" (2012, p. xi). There are plenty of websites which post their own lists of film noirs and frequently the lists differ significantly. Moreover, some critics claim that the features ascribed to the classic film noir are not always present in such films and not every film which possesses those qualities may be categorized as film noir (Spicer, 2010, p. xl). A British philosopher Steve Neale claims that it is impossible to homogenise the tendencies and trends associated with film noir and confine them in one notion - film noir. He argues that such categorization will "lead to incoherence, imprecision, and inconsistency - in the provision of the criteria, in the construction of a corpus, or in almost any interpretation of their contemporary socio-cultural significance" (qtd. in Mayer, 2007a, p. 5). However, difficult it may be to limit the whole phenomenon to a single name, many critics have agreed to employ the notion.

The term "film noir," meaning "black cinema," was coined by French critic Nino Frank who used it in his review of four famous films, The Maltese Falcon (1941), Double Indemnity (1944), Murder, My Sweet (1944), and Laura (1944), written in 1946 (Spicer, 2010, p. xxxviii). Nevertheless, it was not until 1972, a year in which Paul Schrader's essay Notes on Film Noir was published, that the term was finally acknowledged by the motion picture industry. Schrader defined film noir, provided chronology and a list of most significant films, stressing the importance of the period in film history (2010, p. xxxviii). He claimed that "film noir spoke to a new generation of Americans disillusioned by Vietnam and should become part of the vocabulary and thinking of young American filmmakers in order to critique the corruption and inequalities of American society" (2010, p. xxxviii). One could argue that the problem of defining film noir may be caused by its retrospective label. The term was not used by the filmmakers in the 1940s and 1950s, and it refers precisely to those times; therefore, it is difficult to establish any features of those films based on the trade documents (2010, p. xxxix).

In What Is Film Noir?, William Park claims that in the early 1940s, film noir became a genre, since there had already been a group of films similar to each other, sharing certain characteristic features (2011, p. 133). In Film Noir Style, Brian McDonnell explains that some academics distinguish film noir as a genre because:

The films of the classical noir cycle often looked so different, both from their contemporaries (1940s and 1950s westerns, musicals, costume epics, and so on) and from the average Hollywood releases of the late 1960s and early 1970s that were the standard cinema diet of the authors of the first writings on film noir. (2007, p. 70)

Another scholar, Foster Hirsch, also supports the idea of film noir being a genre. Furthermore, he even claims that it is "as heavily coded as the Western" (1981, p. 72). Hirsch argues that in fact the titles of the films are the very indicators of 
the "thematic and tonal similarities within the films" (1981, p. 10) and, therefore, help in generic identification. The titles such as The Sleeping City (1950), They Won't Believe Me (1947) or Framed (1947) already suggest what the topic of the film is or indicate its central focal point (Krutnik, 1991, p. 18). Nevertheless, more frequently it is not even the titles that indicate a genre, but promotional tag-lines on film posters, for instance, "From the moment they met it was murder" on Double Indemnity's bill (1991, p. 18).

In addition to being a genre, film noir may also be categorized as a style. Park argues that "its combination of chiaroscuro, depth of focus, oblique camera angles, a disjointed and fragmented narrative, all supporting an appropriately gloomy world view, initiated the style" (2011, p. 134). Moreover, he also categorizes film noir as a period by virtue of its murky outlook that is characteristic of World War II or post-war films and dates the genre back to the 1940s and 1950s. In What Is Film Noir? it reads as follows:

The violence of the war, the weakening of the Production Code, guilt over victory, the fear of success, the difficulty of readjustment, political witch hunts, the flight to the new suburbs, and the fear of the bomb all contributed to the phenomenon. Technicolor, television, the collapse of the Studios and with them the Production Code, the Cold War, its spies and agents, and primarily the rise of a new audience, the Baby Boomers, which we call the 1960s, all put an end to the period, but, as we have seen, the genre survived. (Park, 2011, p. 134)

Not only did film noir survive, but also recently one can notice resurgence of interest in the genre among both directors and film historians.

The coverage of film noir resulted in the discussion around the subject, which led to the publishing of many books concerned with the problem of defining the term. There have been international film festivals held both in the United States and Europe, devoted especially to film noir. The 1990s is the time, when neo-noir films flourished. Films like Pulp Fiction or The Usual Suspects truly caught public attention and were nominated for the most important movie awards (Lyons, 2000, p. 1). The author of Death on the Cheap: The Lost B Movies of Film Noir enumerates a variety of influences that contributed to the emergence of neo-noirs:

A flood of foreign auteurs fled Europe with the rise of Hitler and brought with them to America the artistic style of German expressionism; American directors were exposed to French poetic realism; [...] Hollywood recognized and played on the popularity of the "hard-boiled" writers of the 1930s by putting their novels and short stories on film; soldiers returning home from World War II brought with them a postwar cynicism and hardened views of violence; and public paranoia about The Bomb grew with the advent of the Cold War. (Lyons, 2000, p. 2)

All neo-noirs refer, in one way or another, to the classic film noir, therefore, in order to analyze the contemporary versions of the genre one has to understand 
the idea of the classic film noir itself. Film noirs are often called "B" films because they were frequently shot on a low-budget. The production of B films was cheaper as they did not require much lighting and the cast included only a few actors. In addition to that, the story was limited to a small set and could be told in up to eighty minutes (Lyons, 2000, p. 4). The features that film noirs or "black films" share are thematic as well as stylistic. Lyons writes that film noirs are "dark in both look and mood" (2000, p. 2). The action of the movies takes place usually at rainy nights, on lonely streets, in narrow alleys, shabby diners or claustrophobic hotel rooms (2000, p. 2). The main characters in such films are mostly convicts, killers, corrupt cops and femme fatales. The universe is an orderless, hostile place ruled by paranoia, obsession and alienation. The entrapped inhabitants of this universe are victims of fate (2000, p. 3). A film critic and editor Paul Duncan writes:

When I think of Film Noir, I think of stillness and silence. I think of a pure black screen with tiny pinpricks of white trying to break through. The image is of the central character thinking. He is thinking about all the bad things that are about to happen to him. He is not happy. He knows that shit happens, but why does it have to happen to him? Film Noir gives him the answer: Why not? (2006, p. 11)

Doomed love is usually the central theme in film noir. The corrupt and degrading world makes the viewer feel that something wrong is going to happen to the protagonist, thus, the story evolves into tragedy. The main question is not if the main character gets to the horrible end that the audience dreads, but when it will happen (Duncan, 2006, p. 16).

\section{FEMME FATALE IN FILM NOIR}

The Film Studies Dictionary defines femme fatale as follows: "from the French for »fatal woman«, a female character who uses her beauty to lure and entrap men, leading to their downfall and, usually, death" (Blandford, 2001, pp. 95-96). A professor of film and media Mary Ann Doane is even more precise, describing femme fatale as:

The figure of a certain discursive unease, a potential epistemological trauma. For her most striking characteristic, perhaps, is that she never really is what seems to be. She harbors a threat which is not entirely legible, predictable, manageable. In thus transforming the threat into a secret, something which must be aggressively revealed, unmasked, discovered. (1991, p. 1)

Although the figure of femme fatale is not restricted to film noir per se, as she appears in variety of genres, e.g. Victorian novel, Gothic novel or even poetry, 
one could say she is especially prominent in film noir. A femme fatale portrayed in film noir is a deadly weapon with a license to kill. Her sexuality is aggressive, which makes her a lot more interesting than the dull men who end up as her victims (Park, 2011, p. 118). An American theorist Philip Green writes that "films noirs were usually movies about strong men brought to their knees by a malignant fate, most often coded as »woman «" (1998, p. 204).

In film noir the male protagonist, whether he is a private detective, a cop or a journalist, is usually torn between two women: the dutiful and the beautiful. The dutiful woman is trustworthy, caring, and honest, she loves him deeply and is quite attractive. The beautiful woman is, in fact, unbelievably gorgeous, yet unreliable, deceitful, does not care for him or fall for him. Nevertheless, she has everything that excites the hard-boiled character. Femme fatale is usually in a relationship with a powerful, often older man, whom she wants to deceive and take all of his money, using for it the male detective who is enchanted by her looks (Duncan, 2006, p. 12). An American professor Julie Grossman claims that it is not only her appearance that makes femme fatale so powerful:

Most "femmes fatales" are sexual, but that's not their main appeal [...]. It is the leading female's commitment to fulfilling her own desires, whatever they may be (sexual, capitalist, maternal), at any cost, that makes her the cynosure, the compelling point of interest for men and women. $(2009$, p. 3$)$

Suffice it to say, the protagonist is eventually mentally and physically abused by the gorgeous woman and once again has to deal with alienation (Duncan, 2006, p. 12).

Women are undoubtedly crucial elements in film noir's world. The most famous example of a truly noirish femme fatale is Phyllis Dietrichson, played by Barbara Stanwyck in Wilder's Double Indemnity (1944). She seduces Walter Neff, an insurance agent, and manages to convince him to kill her husband, having taken out insurance with a "double indemnity" clause, which, in case her husband was killed, would provide her with double amount of money from the insurance company. Not only does she want Walter to kill her husband, but she also convinces him to deal with the formalities concerning closing the deal with the insurance company in which he works. Phyllis truly is a malicious woman with a face of an angel and a soul of a devil.

It is worth mentioning that even the actresses chosen to play femme fatales do look, to say the least, appropriately to their roles. One of the most famous actresses who played femme fatales is Veronica Lake. Her name appears in James Ellroy's L.A. Confidential, as the main woman figure in this novel, as well as film, is characterized to look like Lake. The psychologist Scott Snyder describes Veronica Lake as follows: 
[Her] face barely moved. Her voice and bearing were notable for their angularity, frigidity, and sleekness. She was shy, yet sexy, with a hazy, muddled quality; chiseled features and flawless beauty highlighted by a translucent Nordic complexion completed the picture. An efficient, dominating, wise-cracking quality set her apart. (2001, pp. 162-163)

Andrew Dickos speaks of six descriptions that may be applied to the women portrayed in classic film noir. Firstly, he distinguishes the female character, who does not necessarily have to be a fatal woman, yet is very sexual, usually in her twenties to forties, and uses her sexuality to create a tension between her and the male characters, just as Cora Smith does in The Postman Always Rings Twice (1946). The second type of woman is a female who specializes in betrayal, e.g. Leonora Ohlrig in Caught (1949). Not always does she betray her man out of hatred, anger or to protect herself; sometimes she does it to, as she understands it, save him or simply love him. Thirdly, Dickos mentions that if the female character is neither a devoted lover nor a femme fatale, she is often a clever but conservative girlfriend or, even better, a wife. Good examples of such femme fatales are Peg Born in Body and Soul (1947) and Sally Lord in Sorry, Wrong Number (1948). Helen Brent from Born to Kill (1947) is a representative of the fourth type - a femme fatale, who is motivated by three things: sex, wealth and control. She uses sex out of lust, covets wealth because of the power that she gains thanks to it and needs to feel in control of everyone and everything. Kitty Collins from The Killers (1946) represents yet another type of femme fatale, which Dickos calls an "enigma." The last type of a woman in film noir is the femme fatale who inevitably has to die or, at least, be arrested for the crimes she has committed, like Diane Tremayne in Angel Face (1953). All of the types of femme fatales that Dickos provides have one denominator which is the disruption of the status quo against the society as such (Dickos, 2002, pp. 161-163).

It is essential to add to the typology mentioned above yet another type of a femme fatale which appears usually in retro-noir films, namely the pastiche of femme fatale. A good example of such a fatal woman is Lynn Bracken from James Ellroy's L.A. Confidential. Such a woman "looks like, but does not act like, a classic noir femme fatale" (Wager, 2005, p. 28). She is a very genuine imitation of femme fatale. Retro-noir is a type of a neo-noir film, which is set in the 1940s-1950s, but shot in contemporary times, often commenting on modern issues while referring to the earlier times. The films portray "violent and repressive white male power and female passivity" (2005, p. 22). While neo-noir presents new gender roles for males and females, showing femme fatale as a powerful woman who triumphs and does not wind up confined by marriage or, even worse, behind prison walls, retro-noir represses femininity by portraying women as fragile and passive. Since 
retro-noir narratives are set in the past, they can support "patriarchal femininity" (2005, p. 27) without confronting with modern feminism and being accused of chauvinistic approach to women (2005, p. 27).

\section{THE NOIR CITY}

Some film noirs are set in small towns or have rural settings, yet the vast majority of film noirs focus on big cities "where the pressures and angst of modern life and the sense of alienation, paranoia, and violence are intensified" (Spicer, 2010 , p. 45). As the city plays a major role in film noir, even the titles of the films frequently include the word "city" - Cry of the City (1948), Dark City (1950), Night and the City (1950), While the City Sleeps (1956) or City of Fear (1959). Urban setting of film noir has its roots in hard-boiled literature, which was mostly preoccupied with the city. Andrew Spicer claims that "in the noir city there are no bonds and communities, but a world of aggressive and threatening strangers, knowing no loyalties, its protagonists trapped and fearful in the dark, wet nighttime streets that glisten with reflected neon lights" (2010, p. 45). The city as a focal point of film noir is "a key genre characteristic" (McDonnell, 2007, p. 47). It is not uncommon to find a classic film noir with a city, or a reference to a city, in its title. There are movies which include just a word "city" in their titles, such as Dark City (1950) or The Naked City (1948). Some titles already inform about the place where the narrative is set, for instance, The Phenix City Story (1955) or New York Confidential (1955). Others underscore the word "street" in their headlines, for example, Scarlet Street (1945) and Mystery Street (1950). In addition to that, some films are less explicit, thus employing metaphors to refer to the brutality and savagery of the urban life: The Human Jungle (1954) or The Asphalt Jungle (1950) among others (McDonnell, 2007, p. 47).

In film noir, the atmosphere of the city, as a place of alienation, loneliness, darkness and danger, is reflected in the city dwellers, who are nothing like the characters from the traditional Hollywood movies:

The typical city dwellers of such stories are existential heroes, loners alienated in and by the city, which is impersonal and isolating. They are observed scurrying furtively beneath the street lights and along the alleyways and wet streets. They are revealed sitting alone in a darkened room, fearful and lonely. These protagonists seem so different from the heroes of more traditional Hollywood films, who occupy sunny urban landscapes, but there are sometimes hints that the shadowy city of sin and crime is present all along, lying below the shiny surface of those movies, if only the protagonists could see it. (McDonnell, 2007, p. 49) 
Sometimes noir productions, such as Kiss Me Deadly (1955), focus on the contrast that the city stands for. They present society divided by money in which one can perceive the city through the luxury of the spacious apartments contrasted with the smoke-filled pubs and dingy diners. Moreover, noirs present city as a liminal, impermanent and lonesome place:

Because film noir deals with life-on-the-edge, the noir city is symbolically homeless and impermanent, populated by drifting anomic loners who are outsiders, without a defined role or function. There is a concentration on transient, liminal spaces: hotel lobbies, bus terminals, train stations, markets, racetracks, and sports arenas; and on the precarious: rooftops, walkways, bridges, high window ledges, unlit alleys, railroad tracks, and cars. Noir's pervasive existentialism conceptualizes the city as an urban jungle, a bewildering labyrinth and a trap. (Spicer, 2010, p. 46)

The noir city is therefore a lonely place where one is a victim of its alienating nature, trapped in a jungle or a labyrinth of one's fears and anxieties.

The city in film noir is a study field of American critic and novelist, Nicholas Christopher. In Somewhere in the Night: Film Noir and the American City, Christopher describes the city's importance in film noir genre:

However one tries to define or explain noir, the common denominator must always be the city. The two are inseparable. The great, sprawling American city, endlessly in flux, both spectacular and sordid, with all its amazing permutations of human and topographical growths, with its deeply textured nocturnal life that can be a seductive, almost otherworldly labyrinth of dreams or a tawdry bazaar of lost souls: the city is the seedbed of noir. (1997, p. 37)

The scholar analyzes the city as a three-dimensional labyrinth. Firstly, he approaches the city as a physical labyrinth made of streets, apartments, tunnels, offices and so on. Secondly, he speaks of the interconnections that the characters create between one another, the bounds of space, time and chance. Finally, he discusses the protagonist's actions, which are result of the city's machinery workings - its culture, politics, laws and networks (Christopher, 1997, pp. 16-17).

Literary critics not only compare the city to the labyrinth, but also often discuss it in terms of a trap. Rob White comments on the notion of the city as follows:

A city has no meaningful reality. The same street or building exists differently, depending on the point of view. It is not the same for the shopper, the lost child, the man on the run, the pickpocket, the immigrant, the policeman, the beggar, the tourist, the terrorist or the bomber pilot thousands of feet above [...]. There are traps all about and ambush is always expected. Often it comes, if the purposefulness is forgotten or made impossible by injury, delirium, grief or obsession. In film after film, characters stumble along a street, their minds disintegrating. (qtd. in McDonnell, 2007, p. 52) 
All in all, the city as presented in film noir is a dangerous jungle, an infinite labyrinth and an unexpected trap in which alienation is not the only problem which the characters have to deal with.

Since the city plays a major role in film noir, some academics distinguish many types of noirs, such as L.A. noir, San Francisco noir or New York noir. It comes as no surprise that the most recognizable of all is L.A. noir, as Los Angeles is the city known for film production studios and, first and foremost, for Hollywood, which is located there. The narratives of the classic film noir were mostly set in Los Angeles so as not to travel to any other location and minimize expenses. Some journalists popularized the name "Los Diablos" instead of Los Angles to emphasize that the city is not angelic, but rather diabolical, which tied in with the portrayal of Los Angeles presented in film noir (McDonnell, 2007, p. 53).

\section{CONCLUSIONS}

Not only has evolution in crime fiction that started back in the 1920s and 1930s influenced the image of a detective presented in literature, but it also gave rise to a new genre in cinematography. Hard-boiled literature and film noir reflect the harsh economic and political reality of those times, where the danger lurks on every corner and the crime is never punished. Noirish world is degenerated, corrupt and full of violence; the dangerous cities in which the narratives are set are portrayed as mazes with no exit or traps that entangle the male detective. In order to face this vicious reality, a private eye must develop a shell that would protect him from the brutality and cruelty of the world. Try as he might, he will eventually end up trapped by femme fatale in the world without order.

\section{REFERENCES}

Blandford, Steve, Barry Keith Grant, Jim Hillier. (2001). The Film Studies Dictionary. London: Arnold.

Chandler, Raymond. (1950). The Simple Art of Murder. Boston: Houghton Mifflin.

Chandler, Raymond. (1960). Fingerman. London: Ace Books.

Christopher, Nicholas. (1997). Somewhere in the Night: Film Noir and the American City. New York: Free Press.

Dickos, Andrew. (2002). Street with No Name: A History of the Classic American Film Noir. Kentucky: The University Press of Kentucky.

Doane, Mary Ann. (1991). Femmes Fatales: Feminism, Film Theory, Psychoanalysis. London: Routledge.

Duncan, Paul. (2006). Film Noir: Films of Trust and Betrayal. Pocket Essentials. 
Green, Philip. (1998). Cracks in the Pedestal: Ideology and Gender in Hollywood. Boston: University of Massachusetts Press.

Grossman, Julie. (2009). Rethinking the Femme Fatale in Film Noir: Ready for Her Close-Up. London: Palgrave MacMillan.

Hirsch, Foster. (1981). The Dark Side of the Screen: Film Noir. New York: Da Capo Press.

Horsley, Lee. (2005). Twentieth-Century Crime Fiction. London: Oxford University Press.

Krutnik, Frank. (1991). In a Lonely Street: Film Noir, Genre, Masculinity. London: Routledge.

Lott, Eric. (2005). Racing the Paradigm: The Whiteness of Film Noir. In: Jans B. Wager (ed.), Dames in the Driver's Seat: Reading Film Noir (pp. 29-35). Texas: The University of Texas Press.

Lyons, Arthur. (2000). Death on the Cheap: The Lost B Movies of Film Noir. Boston: Da Capo Press.

Mayer, Geoff. (2007a). Introduction: Readings on Film Noir. In: Geoff Mayer, Brian McDonnell (eds.), Encyclopedia of Film Noir (pp. 3-18). London: Greenwood Press.

Mayer, Geoff. (2007b). The Hard-Boiled Influence. In: Geoff Mayer, Brian McDonnell, Encyclopedia of Film Noir (pp. 19-46). London: Greenwood Press.

McDonnell, Brian. (2007). Film Noir and the City. In: Geoff Mayer, Brian McDonnell, Encyclopedia of Film Noir (pp. 47-61). London: Greenwood Press.

Naremore, James. (2008). More than Night: Film Noir in Its Contexts. California: University of California Press.

Park, William. (2011). What Is Film Noir? Pennsylvania: Bucknell University Press.

Phillips, Gene D. (2012). Out of the Shadows - Expanding the Canon of Classic Film Noir. Maryland: The Scarecrow Press.

Simpson, Phillip. (2010). Noir and the Psycho Thriller. In: Charles J. Rzepka, Lee Horsley (eds.), A Companion to Crime Fiction (pp. 187-197). New Jersey: Blackwell Publishing.

Snyder, Scott. (2001). Personality Disorder and the Film Noir Femme Fatale. Journal of Criminal Justice and Popular Culture, 8(3), pp. 155-158.

Symons, Julian. (1985). Dashiell Hammett. California: Harcourt, Brace, and Jovanovich.

Spicer, Andrew. (2010). Historical Dictionary of Film Noir. Plymouth: The Scarecrow Press.

Wager, Jans B. (2005). Dames in the Driver's Seat: Reading Film Noir. Texas: The University of Texas Press.

Article submission date: 14.12.2019

Date qualified for printing after reviews: 24.05.2020 